\title{
Globalization of Patent Laws through Trade Agreements, and Pressures on Ethiopia's Patent Regime: The Passenger behind the Wheel
}

Abdulkader Mohammed Yusuf *

\begin{abstract}
Given that patent law emerged in domestic systems, there was an obvious diversity of patent regimes. With the advent of cross-border movement of resources, including inventions, there was a need for a harmonized patent regime. The issue went to another level with the entry into force of the WTO/TRIPS Agreement, which requires WTO members to enact new patent laws or amend existing ones to make them TRIPS compliant. The Ethiopian Patent Law, which was enacted in 1995, is strangely TRIPS compliant, tempting many to think that it had Ethiopia's forthcoming accession in mind. However, with Ethiopia yet to complete the accession process, there are further pressures from industrialized countries to ensure that stringent patent rules are complied with in developing countries. This article examines TRIPS, the Cotonou Agreement and AGOA as effective instruments of ensuring compliance. It is argued that the Ethiopian patent system will continue to observe TRIPS and other standards as dictated by the Global North.
\end{abstract}

\section{Key terms}

Globalization · Harmonization · IP · Patent · TRIPS Agreement · BTA · GSP .

Cotonou Agreement · AGOA

DOI http://dx.doi.org/10.4314/mlr.v12i1.3

Received: 31 March 2018

Accepted: 30 September 2018

This article is licensed under a Creative Commons Attribution-NonCommercialNoDerivs (CC BY-NC-ND)

* Abdulkader Mohammed Yusuf, PhD student and Part-time Lecturer, School of Law, Addis Ababa University; Managing Partner, Anchor Consulting PLC;

Email: abdu.mohammed08@gmail.com / abdu@anchorcplc.com

Frequently used acronyms

ACP African, Caribbean and Pacific LDCs

AGOA African Growth and Opportunity Act PCT

BTAs Bilateral Trade Agreements

EIPO Ethiopian Intellectual Property Office

IP

Intellectual Property
TRIPS Trade Related Aspects of Intellectual Prop. Rights

WIPO World Intellectual Property Organization

WTO World Trade Organization 


\section{Introduction}

Although intellectual property (IP) rights existed for so long in some countries, it is fairly a new area of property rights, particularly as compared with real property rights. IP can be classified into two broad areas: copyright and industrial property. These categories cover areas such as copyright and related rights, trademark, geographical indications, industrial designs and patents. With the development of IP protection pertaining to different areas, there is tension between protecting the interests of creators/inventors and public interest.

Indeed, patent laws have developed fast in the past few decades both at the international and national levels. One can notice the development of international patent laws and harmonization efforts starting from the 1883 Paris Convention. However, the globalization of patent law gained momentum upon the establishment of the World Trade Organization (WTO) in 1995. The Agreement on Trade Related Aspects of Intellectual Property (TRIPS) is one of the regimes under WTO which requires members (including those in the process of accession) to enact new laws or amend existing ones, one of the most important fields being patent.

Ethiopia applied for WTO accession in January 2003 and the Working Party on the Accession of Ethiopia was established in February 2003. ${ }^{1}$ The Ethiopian Patent Law is largely TRIPS compliant in important aspects which tempts us to think that our house is in order, albeit at the cost of citizens. The Ethiopian Patent Law is the manifestation of the pressure of globalization than a domestic policy objective, and it will further be stretched during the accession process if local production capacity (in using certain inventions in Ethiopia) makes progress. The experience of other countries shows this trend, particularly in view of what it entails on domestic policy decision making.

Apart from TRIPS, there are also some bilateral trade agreements (BTAs) that incorporate provisions on IP. Although numerous in number and diverse in nature, this article looks into the impact of the EU-ACP Economic Partnership Agreement, also known as the Cotonou Agreement. ${ }^{2}$ It also explores a Generalized System of Preferences (GSPs), in the form of the African Growth and Opportunity Act (AGOA), which sounds like a non-reciprocal trade benefit but a look at its objectives, the eligibility criteria and the experience of the US vis-á-vis certain Sub-Saharan African countries tells a different story. This can

\footnotetext{
${ }^{1}$ For Ethiopia's accession, see <https://www.wto.org/english/thewto_e/acc_e/a1_ethiopia_e.htm> accessed 28 September 2018.

${ }^{2}$ Partnership Agreement between the Members of the African, Caribbean and Pacific Group of States of the One Part, and the European Community and its Member States of the Other Part, signed in Cotonou on 23 June 2000 (the Cotonou Agreement).
} 
be deduced from the emphasis on patent protection in both the Cotonou Agreement and AGOA.

These arrangements in fact have very serious pressures on developing countries. Developed countries have successfully designed such BTAs/GSPs to exert pressures on developing and least-developed countries (LDCs), in the event that there is any policy space left by the TRIPS Agreement. The number and nature of BTAs that the US, for instance, had designed and concluded with many countries since the aftermath of the Doha Declaration is an example of this trend.

Ethiopia is one of the seventy-eight ACP country members of the Cotonou Agreement. It is also one of the eligible countries to the AGOA initiative. It is interesting to look at the extent to which the EU and the US are using the initiatives to enforce their patent interests on countries like Ethiopia. Indeed, by pushing for the inclusion of IP provisions in the Cotonou Agreement and AGOA, the two trade powers sent a clear signal that they viewed IP protection as an integral component of the 'rule of law' and 'good governance', progress which was vital to maintaining trade preferences, even in the poorest countries. ${ }^{3}$

The main objective of this article is to highlight how the Global North is shaping patent laws through trade agreements. This is done by looking into TRIPS as the primary tool of harmonization. But with Ethiopia yet to become a member of the WTO, it also examines the Cotonou Agreement (a partnership agreement) and AGOA (a GSP) based on the experiences of LDC members of the WTO as well as the EU/US vis-á-vis member/eligible countries.

Apart from this short introduction, the article is organized in five sections. The first section gives some general background on patent and the major theoretical justifications for patent as well as the international efforts of patent protection. Section 2 briefly discusses Ethiopia's patent law, by focusing on some of the pertinent issues with a view to offering a platform for the discussion in the coming sections. This is followed by a section that discusses the TRIPS Agreement and its impacts on the patent laws of WTO members and countries in the accession process. Section 4 explores the potential implications of the Cotonou Agreement on the patent laws of members such as Ethiopia. Section 5 looks into the AGOA initiative.

\footnotetext{
${ }^{3}$ Carolyn Deere (2009), The Implementation Game: The TRIPS Agreement and the Global Politics of Intellectual Property Reform in Developing Countries, Oxford University Press, p. 269.
} 


\section{Theoretical Justifications and Protection for Patent}

\subsection{Patent}

IP, very broadly, means the legal rights which result from intellectual activity in the industrial, scientific, literary and artistic fields. ${ }^{4}$ Generally speaking, IP law aims at safeguarding creators and other producers of intellectual goods and services by granting them certain rights to control the use made of those productions. ${ }^{5}$ Because of the understanding that these creations of the human mind have multifold social and economic impacts, countries have laws on the protection of IP.

IP is divided into two broad areas: copyright and industrial property. A patent is the right granted to an inventor to exclude others from commercially exploiting the invention for a limited period, in return for the disclosure of the invention, so that others may gain the benefit of the invention. ${ }^{6} \mathrm{~A}$ patent is issued, upon application, by a government office, which describes an invention and creates a legal situation in which the patented invention can (normally) only be exploited with the authorization of the owner of the patent. ${ }^{7}$

In order for a certain invention to be patentable, it has to meet a few criteria. These criteria are found both in international agreements and most national patent regimes. Accordingly, the invention is required to (i) consist of patentable subject matter, (ii) be industrially applicable/useful, (iii) be new/novel, (iv) exhibit a sufficient "inventive step" or be non-obvious, and (v) the disclosure of the invention in the patent application must meet certain standards (be sufficiently clear and set out at least one mode for carrying out the invention). ${ }^{8}$

The system is not, however, free from criticisms. One important criticism against patent is that it creates a monopoly over the invention, as a result of which it is up to the patentee to determine the price at which s/he (it) wants to put the invention on the market. Indeed, the temporary monopoly positions involve very large (up to $90 \%$ ) margins on sales where a product is priced monopolistically, although the grant of a monopoly right over an invention may be regarded as a tradeoff between the state and the inventor. ${ }^{9}$

\footnotetext{
${ }^{4}$ WIPO, Intellectual Property Handbook: Policy, Law and Use, WIPO Publication No. 489 2004, p. 3.

${ }^{5}$ Ibid.

${ }^{6}$ Id., p. 17.

${ }^{7}$ Ibid.

${ }^{8}$ Id., pp. 17-21.

${ }^{9}$ See Peter J Groves (1997), Sourcebook on Intellectual Property Law, Cavendish Publishing, p. 112; Getachew Mengiste (2009), 'Impact of the International Patent System on Developing Countries', Journal of Ethiopian Law, Vol. 23. No.1, p. 172.
} 


\subsection{Theoretical justifications for patents}

There are four major theories that justify patents from different perspectives. Proponents of the natural rights theory argue that an inventor has an inherent right in the fruits of his/her intellect which include patents. ${ }^{10}$ Their belief is that "patents are the heart and core of property rights, and once they are destroyed, the destruction of all other property rights will follow automatically. ${ }^{11}$ Natural rights theory is put to practice in many jurisdictions via the provisions of the TRIPS Agreement. Oddi notes that on patentable subject matter, TRIPS implements natural rights theory, by providing that all inventions -including certain categories of inventions that have been traditionally excluded from protection by many countries- are now of such importance to international trade that they must be protected universally. ${ }^{12}$

According to the incentive theory, patents give the patentee a limited monopoly on his invention to recoup his investment in coming up with his invention. Although some inventions take years and substantial resources, they can easily be copied and put to use, thereby hindering the inventor's chance of recouping cost of investment. Thus, it is a disincentive to other potential inventors if temporary monopoly is not given for their inventions. According to the incentive theory, the principal objective of patent systems is to encourage innovation, to promote the development of technology and to foster dissemination of innovative knowledge to the public. ${ }^{13}$

From the perspective of the disclosure theory, the patentee discloses all the information pertaining to his/her invention in exchange for having a certain invention patented. The theory holds that patents are not necessary to induce invention, but rather what patents do is encourage disclosure and, given some assumptions about the transaction costs of licensing the invention, it can be used more widely than it would be without a patent. ${ }^{14}$ The idea of this theory, therefore, is that a patent constitutes a bargain between the inventor and the public, in which the patentee obtains exclusive protection for a set-period of time in exchange for giving the public information about the invention. ${ }^{15}$ Patent

\footnotetext{
${ }^{10}$ Poku Adusei (2013), Patenting of Pharmaceuticals and Development in Sub-Saharan Africa: Laws, Institutions, Practices, and Politics, Springer p. 115.

${ }^{11}$ Ibid.

${ }^{12}$ Id., p. 116.

${ }^{13}$ Tomoko Miyamoto (2008), 'International Treaties and Patent Law Harmonization: Today and Beyond' in Toshiko Takenaka (ed), Patent Law and Theory: A Handbook of Contemporary Research, Edward Elgar, p. 154.

${ }^{14}$ Roberto Mazzoleni and Richard Nelson (1998), 'Economic Theories about the Costs and Benefits of Patents', Journal of Economic Issues Vol. XXXII No. 4, p. 21.

${ }^{15}$ Adusei, supra note 10, p. 119.
} 
laws usually prescribe a certain form through which the disclosure is made, which is assumed to facilitate the way the technology will be worked when the patent expires and helps promote knowledge and be a catalyst for further inventions.

The public benefit theory argues that by coming up with inventions, the inventor is not only benefiting himself through the reward, as the invention by and large also benefits the public. This may be in a variety of forms. First, the public will benefit from the actual invention itself, such as pharmaceutical inventions which treat or cure a disease. Second, the fact that an invention goes to a public domain at the expiry of its protection period benefits the public. Third, as the inventor provides for a clear description of the invention, the public benefits from the knowledge resulting in the invention.

\subsection{National/International Patent Protection}

As with most other areas, the historical development of patent protection clearly shows that patent law emerged in domestic systems. One of the earlier patent laws emerged in the Republic of Venice in 1474, whose underlying purpose was to attract persons with the incentive of a ten-year monopoly right to their 'works and devices. ${ }^{16}$ The next significant legislative development in patent law came in 1624 with the English Statute of Monopolies. ${ }^{17}$ Across the Atlantic, although one can cite two Patent Laws (the 1790 and 1793) the 1836 Patent Act is arguably the first modern patent law in the US. ${ }^{18}$ Moreover, the 1791 French Law on Useful Discoveries and on Means for Securing the Property therein to the Authors and the German Patent Act of 1877 are notable developments. ${ }^{19}$

Patent laws were divergent among various jurisdictions and this may be attributable to two main reasons. First, there is the centuries-old principle of territoriality. ${ }^{20}$ Thus, according to the territoriality principle, IP rights are protected only within and in accordance with the legal rules of the jurisdiction where they have been granted. ${ }^{21}$ Second, the diversity is also attributed to the acts of government in using patent law as a policy tool for economic growth. ${ }^{22}$ Patents protect inventions/technologies which are very important for countries irrespective of their level of development.

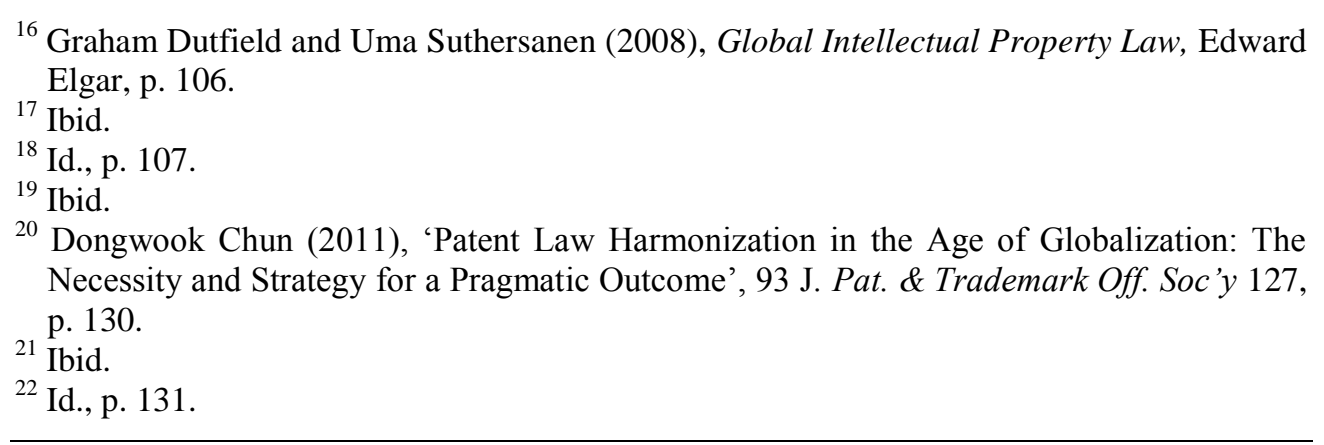


Patent laws indeed induce inventions which are important for a country's development; and it is up to the country concerned to determine whether to have a patent law and, if so, the form it should take. However, as the world became more and more globalized, there was an increasing movement of economic resources beyond one's national border. ${ }^{23}$ The period before the adoption of the Paris Convention was characterized by inadequate protection of foreign inventions and some countries were not even willing to extend protection to foreign inventions. $^{24}$

Since the $19^{\text {th }}$ century, countries and businesses increasingly recognized the value of the IP system as a tool for technological development. ${ }^{25}$ This naturally resulted in moves for the adoption of a few international patent agreements. However, it must be noted that as these international agreements need to be reinforced by domestic patent laws, the harmonization of patent laws became an issue. This is done by either enacting or amending patent laws which, for the most part, finds the justification in the territoriality of patent protection according to which patents are protected within the jurisdiction where they have been granted.

The Paris Convention could be described as the institutionalization of patent system at the international level for the first time and signaled a more global concern for the protection of the intangible assets. ${ }^{26}$ It incorporated three main principles: national treatment, priority rights and common rules. Accordingly, each member country must provide to nationals of other member countries the same protection as it affords to its own nationals (national treatment) and that the filing of an application for a patent in one member country gives a right of priority to the date of that application in respect of corresponding applications filed in other member countries within 12 months of that date (priority right). ${ }^{27}$ The Paris Convention (adopted in 1883) has gone through revisions over the following century to harmonize procedures relating to, inter alia, priority, registration, and licensing. ${ }^{28}$

${ }^{23}$ Id., p. 133.

${ }^{24}$ Israel Begashaw (2011), 'The Ethiopian Patent Regime and Assessment of its Compatibility with TRIPS Agreement' (LL.M Thesis, Addis Ababa University).

${ }^{25}$ Chun, supra note 20, p. 133.

${ }^{26}$ Getachew, supra note 9, p. 178.

27 Anne-Marie Mooney Cotter (2003), Intellectual Property Law, (Cavendish Publishing) pp. 31-32. See also Miyamoto, supra note 13, pp. 157-158.

${ }^{28}$ Laurence Helfer (2015), 'Pharmaceutical Patents and the Human Right to Health: The Contested Evolution of the Transnational Legal Order on Access to Medicines', Duke Law School Public Law \& Legal Theory Series, No. 2016-18, p. 314. 
Although the Paris Convention had established fundamental principles and some substantive rules, national procedural rules continued to be significantly different, while international movement of goods and services expanded considerably since the adoption of the Paris Convention. ${ }^{29}$ The Patent Cooperation Treaty (PCT), an agreement for international cooperation, with regard to the filing, searching and preliminary examination of patent applications and dissemination of technical information contained in patent applications, was adopted in 1970 with a view to streamlining the patent granting procedures at the global level. ${ }^{30}$ It entered into force in 1978. Whereas the Paris Convention dealt with substantive issues of patent protection, the PCT deals with procedures to obtain international patent protection. ${ }^{31}$

Although the PCT has greatly simplified the filing of patent applications at the international level, substantive patentability requirements varied significantly in different jurisdictions. ${ }^{32}$ The negotiation of harmonization of patent law started in 1985 under the auspices of the WIPO. The negotiation addressed a number of substantive issues, the harmonization of which was considered indispensable for a better international patent system. ${ }^{33} \mathrm{~A}$ draft 'Treaty Supplementing the Paris Convention as far as Patents are Concerned' (draft 1991 Patent Harmonization Treaty) was discussed at the first part of the Diplomatic Conference held in The Hague in $1991 .^{34}$

\section{The Ethiopian Patent Law}

The Inventions, Minor Inventions and Industrial Designs Proclamation (enacted in 1995) governs patent protection in Ethiopia. The Proclamation defines patent as a title granted to protect inventions. ${ }^{35}$ An invention is patentable if it is new, ${ }^{36}$

${ }^{29}$ Miyamoto, supra note 13, p. 161.

${ }^{30}$ Ibid. See also Cotter, supra note 27, p. 32; and Getachew, supra note 9, p. 179.

${ }^{31}$ Randy Campbell (2003), 'Global Patent Law Harmonization: Benefits and Implementation', Ind. Int'l \& Comp. L. Rev. Vol. 13:2, p. 609.

${ }^{32}$ Miyamoto, supra note 13, p. 164.

${ }^{33}$ Ibid.

${ }^{34}$ Ibid.

${ }^{35}$ Inventions, Minor Inventions and Industrial Designs Proclamation No. 123/1995, 54 ${ }^{\text {th }}$ Year, No. 25 (The Patent Law) Art. 2 (5). An invention is defined as an idea of an inventor which permits in practice the solution to a specific problem in the field of technology.

${ }^{36}$ The Law considers an invention as new if it is not anticipated by prior art, which consists of everything disclosed to the public, anywhere in the world, by publication in tangible form or by oral disclosure, by use or in any other way, prior to the filing date or, where appropriate, the priority date, of the application claiming the invention. See the Patent Law, Art. 3(3). 
involves an inventive step ${ }^{37}$ and is industrially applicable. ${ }^{38}$ Hence, once a patent is granted, a patentee has the exclusive right to make, use or otherwise exploit the patented invention, and a third party cannot exploit the patented invention without securing the patentee's consent. 39

Conversely, the Law excludes the following from patentability:

- inventions contrary to public order or morality;

- plant or animal varieties or essentially biological processes for the production of plants or animals;

- $\quad$ schemes, rules or methods for playing games or performing commercial and industrial activities and computer programmes;

- discoveries, scientific theories and mathematical methods;

- methods for treatment of the human or animal body by surgery or therapy, as well as diagnostic methods practiced on the human or animal body;

- $\quad$ works not protected by copyright. $^{40}$

The right to a patent belongs to the inventor. ${ }^{41}$ Where two or more persons have jointly made an invention, the patent belongs to them jointly. ${ }^{42}$ The right to a patent for an invention made in the execution of a contract of service or employment, unless otherwise agreed, belongs to the person who commissioned the work or the employer. ${ }^{43}$ On the contrary, inventions made without any relation to an employment or service contract and without the use of the employer's resources, data, means, materials or equipment belongs to the employee. $^{44}$ Inventions made by the employer or person commissioned which result from both the personal contribution of the author and the resources, data, means, materials or equipment of the employer will be owned jointly in equal shares. $^{45}$

As indicated earlier, the Ethiopian Patent Law protects inventions, whether products or processes. Prior to TRIPS, many developing countries used to only

\footnotetext{
${ }^{37}$ An invention involves an inventive step if, having regard to the prior art relevant to the application, it would not have been obvious to a person having ordinary skill in the art. See Art. 3(4) of the Patent Law.

${ }^{38}$ An invention is considered as industrially applicable where it can be made or used in handicraft, agriculture, fishery, social services and any other services.

${ }^{39}$ See the Patent Law, Art. 22.

${ }^{40}$ Ibid. Art. 4.

${ }^{41}$ Id., Art. 7 (1).

${ }^{42}$ Id., Art. 7 (2).

${ }^{43}$ Id., Art. 7 (3).

${ }^{44}$ Id., Art. 7 (4).

${ }^{45}$ Id., Art. 7 (5).
} 
protect process patents, and not product patents. If the patent is granted for the process, a manufacturer may produce a product through a different process. This is important for certain sensitive sectors such as pharmaceuticals. The TRIPS Agreement came up with the requirement that patents be available for products and processes. But Ethiopia is not a member of the WTO, and the TRIPS Agreement is not applicable. It is to be noted that LDCs normally enjoy some exceptions during the transition period.

Prior to TRIPS, countries used to exclude sectors from the protection of certain inventions such as pharmaceuticals. Indeed, international conventions prior to TRIPS did not specify minimum standards for patents. ${ }^{46}$ At the time that negotiations began, over 40 countries in the world did not grant patent protection for pharmaceutical products. ${ }^{47}$ Under the Ethiopian system, however, patent is available in almost all fields of technology, provided that the inventions satisfy the requirements provided for therein and subject to the exceptions.

The other area that is substantially influenced by TRIPS is duration of a patent. Although the Paris Convention had been silent on the question of patent duration, TRIPS demands a minimum period of protection for twenty years. ${ }^{48}$ In Ethiopia, a patent is granted for an initial period of fifteen years, with a possibility of extension for five more years if there is proof that the invention is being properly worked in the country. ${ }^{49}$ This is particularly problematic when it comes to certain sensitive inventions such as pharmaceutical patents, where the patent term coupled with the extension, have huge implications on access to medicine.

Compulsory licensing is another debatable issue in the Ethiopian system. Although compulsory license is envisaged under the Patent Law, one may raise questions on the grounds for the application and grant of such license. A compulsory license may be granted if an invention depends on another patented invention or if a patentee fails to work his/her invention in Ethiopia and fails to justify his/her inaction within 3 years from the day of grant or 4 years from the filing date. ${ }^{50}$ There is also the requirement of furnishing a proof that prior negotiations towards a voluntary license could not be concluded. ${ }^{51}$ Notably, even the TRIPS Agreement has relatively relaxed the grounds for the grant of compulsory license than the Ethiopian Patent Law. For instance, the

\footnotetext{
${ }^{46}$ For the TRIPS Agreement and its impacts on pharmaceuticals and health products, see <http://www.who.int/medicines/areas/policy/wto_trips/en/> accessed 19 September 2018.

${ }^{47}$ Ibid.

${ }^{48}$ Deere, supra note 3, p. 66.

${ }^{49}$ The Patent Law, Art. 16.

${ }^{50}$ Id., Art. 29

${ }^{51}$ Id., Art. 31
} 
requirements mentioned above may be waived in cases of national emergency or other circumstances of extreme urgency or in cases of public non-commercial use. $^{52}$

The Law further states that a patent shall be invalidated upon the request of an interested party if it is proved that the patent is not patentable or the description does not disclose the invention in a manner sufficiently clear and complete. ${ }^{53}$ However, one may easily note that Ethiopia's patent law does not envisage pre-grant patent opposition. Patent systems that require the publication of pending patent applications prior to grant and that allow opposition any time prior to grant ${ }^{54}$ are very important.

One may argue that the Ethiopian Patent Law does not promote local interests. A case in point in this respect is the fact that the number of patents issued by the Ethiopian Intellectual Property Office (EIPO) to Ethiopian nationals is so insignificant. This makes it clear that the country relies on technologies from abroad. A strong patent system may impair the capacity of potential recipients in the developing countries to gain access to essential technologies; and that stronger IPs have a considerable negative impact on the process of catching up in developing countries by excluding imitation through reverse engineering on a wider scale while the cost of obtaining licenses are likely to increase, if they are obtainable at all..$^{55}$

This evokes a question as to why the Ethiopian Patent Law was designed this way. There are arguments that stronger patent protection encourages local innovation and facilitates technology transfer. Whether patent protection encourages local innovation, facilitates transfer of technology and thereby promotes economic development or whether it hurts technological progress and economic development by restricting access to knowledge has been the subject of discourse for a long time. ${ }^{56}$ There is no empirical evidence that categorically

\footnotetext{
${ }^{52}$ The TRIPS Agreement, Art. 31 (b).

${ }^{53}$ The Patent Law, Art. 36 (1).

${ }^{54}$ See Chan Park et al. (2013), Using Law to Accelerate Treatment Access in South Africa: An Analysis of Patent, Competition and Medicines Law, United Nations Development Programme, pp. 54-55.

55 Carlos Correa (2005) 'Can the TRIPS Agreement Foster Technology Transfer to Developing Countries?' in K Maskus and J Reichman (eds.), International Public Goods and Transfer of Public Goods under a Globalized Intellectual Property Regime 254; Habtamu Hailemeskel (2011), 'Designing Intellectual Property Law as a Tool for Development: Prospects and Challenges of the Ethiopian Patent Regime' (LL.M Thesis, Addis Ababa University).

56 Fikremarkos Merso (2012), 'Ethiopia's World Trade Organization Accession and Maintaining Policy Space in Intellectual Property Policy in the Agreement on TradeRelated Aspects of Intellectual Property Rights Era: A Preliminary Look at the Ethiopian
} 
makes the point that IP/patent protection promotes science and technology or transfer thereof. The channels of acquiring knowledge for LDCs are usually imitation of existing technologies, reverse engineering and applying knowledge and technologies described in patent papers; and patents may in fact become barriers in acquiring technology for such countries. ${ }^{57}$

Advocates for strong patent systems argue that such a system would increase FDI, and associated technology transfers to developing countries. ${ }^{58}$ They argue that there is a direct link between strong patent protection and an increased inflow of FDI citing the increase in certain countries. ${ }^{59}$ This, however, may not work in every country and very much depends on the sector concerned. Although patent protection has a significant contribution in attracting FDI, this impact depends on some other important social, policy and other factors.

\section{Globalization of Patent Laws through the TRIPS Agreement}

\subsection{General}

The Convention Establishing the World Intellectual Property Organization (WIPO) was adopted in 1967 and entered into force in 1970. The WIPO is responsible for promoting IP and administers 23 international treaties on IP matters and has a membership of over 180 countries. ${ }^{60}$ Yet, it is perceived as a toothless tiger in the sense that developed countries were 'dissatisfied' with the implementation of the IP rights as WIPO did not have an effective enforcement system. ${ }^{61}$ Accordingly, industrialized countries were successful in making sure that IP is one of the Agreements of the WTO and that no reservation or derogation may be made by its members.

As noted earlier, one of the issues tabled during the Uruguay Round of negotiations, which lasted between 1986 and 1994, was an agreement on IP. Along with an Agreement on Services, the negotiation and later the inclusion of an Agreement on IP marks a clear departure from the original General Agreement on Tariffs and Trade (GATT) 1948, whose application only extended to Trade in Goods. As Subhan notes, no other Agreement has been as

Patent Regime in the Light of the Agreement on Trade-Related Aspects of Intellectual Property Rights Obligations and Flexibilities', The Journal of World Intellectual Property Vol. 15, No. 3, p. 172.

${ }^{57}$ Ibid.

${ }^{58}$ UNCTAD (1996), The TRIPS Agreement and Developing Countries, Geneva, in Getachew, supra note 9, p. 185.

${ }^{59}$ See Kamil Idris (2002), Intellectual Property: A Power Tool for Economic Growth, Geneva, in Getachew supra note 9, p. 185.

${ }^{60}$ Prabodh Malhotra (2010), Impact of TRIPS in India: An Access to Medicines Perspective, Palgrave Macmillan p. 10.

${ }^{61}$ Ibid. 
much of a driving force behind the globalization and liberalization of trade barriers as the set of these agreements that comprise the WTO. ${ }^{62}$

Hence, while the pre-TRIPS global IP system provided 'a menu of treaties' from which countries could 'pick and choose and in some cases make reservations to', TRIPS obliges all WTO members to implement minimum standards of protection within specified deadlines for virtually all categories of IP including patents. ${ }^{63}$ TRIPS puts new and unparalleled emphasis on making privately held IP rights enforceable, demanding stronger provisions in national IP laws to promote enforcement of IP rights at the border and within the domestic market. $^{64}$

The inclusion of IP rights as one of the single undertakings of the WTO package has since received criticisms from different fronts. Some writers hold that the TRIPS Agreement was unnecessary as most of its functions have, for up to a century, been addressed by conventions such as the Paris Convention, Rome Convention, and the UN-based WIPO. ${ }^{65}$ However, a critical look at how things evolved clearly reveals that an international patent regime with stronger enforcement was inevitable. The adoption of the PCT and the 1985 WIPO Harmonization Discussions are evidence of how developed countries were persistent in having certain forms of international patent regimes with strong enforcement mechanisms. $^{66}$

${ }^{62}$ Junaid Subhan (2006), 'Scrutinized: The TRIPS Agreement and Public Health', McGill Journal of Medicine 9(2) p. 153.

${ }^{63}$ Deere, supra note 3 , p. 10 . The TRIPS Agreement, inter alia, aims to:

(a) harmonize IP rights protection by providing for the minimum standards that should be adopted by member states;

(b) enhance and broaden the scope of protection of patents by (i) reducing the scope of various restrictions and safeguards which used to be incorporated by national laws to protect the public interest and control abuse of a right by the patentee (ii) expanding the scope of duration of protection by, for instance, requiring that patent protection shall be available in all fields of technology (Art. 27 (1) and making the duration of a patent 20 years (Art. 33)

(c) providing a mechanism that ensures effective enforcement of rights; violation of IPRs and failure of member states to provide with an effective enforcement of the same will entail severe consequence such as loss of trade rights and imposition of sanctions.

See Getachew, supra note 9, p. 181.

${ }^{64}$ Deere, supra note 3, p. 10-11.

${ }^{65}$ Malhotra, supra note 60, p. 10.

${ }^{66}$ The US "Special 301" procedure is the most well-known example of such national strategies. It authorized the US Trade Representative to investigate countries with weak intellectual property protection. The US deployed Special 301 against more than a dozen countries between the 1970s and early 1990s, successfully pressuring governments to 
As one of the protected fields, patents should be available for any invention, whether product or process in all fields of technology. ${ }^{67}$ Two major issues have, thus, been introduced by the TRIPS. First, in the pre-TRIPS era, developing countries were only giving process patents and not product patents. Second, while many countries did not recognize certain areas as patentable subjectmatters, under the TRIPS all inventions are patentable irrespective of their field of technology.

For the most part, developed countries already had TRIPS standards and IP institutions in place and needed to make only minor revisions to domestic IP laws and administration to implement TRIPS. ${ }^{68}$ For developing countries, on the other hand, implementation of TRIPS requires them to raise their IP standards (increasing the terms and scope of protection). ${ }^{69}$ For most countries, this involves a complex set of reforms to update or redraft existing laws, adopt new laws, and/or promulgate new administrative regulations and guidelines. ${ }^{70}$

Needless to say, the fact that WTO Members are required to bring their domestic patent laws in compliance with the minimum TRIPS standards is a clear instance that shows the impacts of the globalization of patent law. Developed countries were given a one year period to be fully TRIPS compliant, while developing countries were given 5 years to have their patent laws conform to the TRIPS. ${ }^{71}$ LDC members of the WTO were initially given 11 years which has now been extended to 2021. Hence, save these LDC members of the WTO, ${ }^{72}$ the other members of the WTO have made their domestic patent laws compatible with the TRIPS. This implies that such moves are contributing

enact IP reforms that benefitted foreign industries, including US based pharmaceutical companies. See Helfer, supra note 28, p. 315.

${ }^{67}$ The TRIPS Agreement, Art. 27.

${ }^{68}$ Deere, supra note 3, p. 11.

${ }^{69}$ Ibid.

${ }^{70}$ Ibid.

${ }^{71}$ Although developing countries were given period of compliance until 2000, countries like India that had previously disallowed product patents in pharmaceuticals were granted additional five years i.e. 2005. See Malhotra, supra note 60, p. 19.

${ }^{72}$ However, this must not be taken to mean that all LDC members of the WTO have not made their domestic patent laws compatible with the TRIPS. The effect of globalization of patent laws has proved to be powerful in the sense that powerful states are forcing poor countries to come up with a patent regime that best serves their interest. This is done, inter alia, through the use of BTAs. Moreover, the experience of certain LDCs that have finalized their accession process to the WTO shows that there are certain TRIPS-Plus requirements whereby these LDCs are required to conform to the entire TRIPS provisions, notwithstanding the transitional arrangements envisaged under the TRIPS Agreement and reinforced by the WTO Ministerial Conference Decision. 
towards a harmonized patent law when it comes to certain important aspects such as patentable subject matter and term of protection.

\subsection{TRIPS and the Ethiopian patent law}

Ethiopia is currently in the accession process to join the WTO. The WTO Agreement $^{73}$ envisages two kinds of membership: original membership and membership through accession. Countries that were the Contracting Parties of the GATT are referred to as the original members of the WTO. ${ }^{74}$ At the end of 1994, GATT had 123 members, which accordingly became original members of the WTO. Accession is the other way through which membership of the WTO is acquired. ${ }^{75}$ Over two dozen countries have become members of the WTO, after having completed the rigorous accession process which, in most cases, takes several years.

For Ethiopia to become a member of the WTO, it has to go through the scrupulous accession process of the WTO. A country (or a separate customs territory) may become WTO observer before making an application to the WTO. Accordingly, Ethiopia became an observer in 1997 and made a declaration of intent to apply for accession. ${ }^{76}$ It later submitted its application in January 2003, and a Working Party was established in February of that year and the negotiations are still underway. ${ }^{77}$

The accession process is carried out on two parallel and often overlapping tracks. The first track is multilateral that aims to find out the relevant laws, policies and practices of the acceding country and ensure that they are brought into conformity with WTO rules, and the second track is a bilateral track that aims to extract as many specific commitments from the acceding country. ${ }^{78}$ The one that is of immediate importance here is the multilateral track. It starts with the applicant country's submission of a Memorandum on its Foreign Trade

${ }^{73}$ Also referred to as the Marrakesh Agreement, the WTO Agreement was adopted on 15 April 1994 and entered into force on 1 January 1995. It incorporates, in its Annexes, the Multilateral Trade Agreements on Trade in Goods, Services and IP, the Understanding on the Settlement of Disputes, the Trade Policy Review Mechanism. In Annex IV, it also has Plurilateral Trade Agreements for countries that have accepted them.

${ }^{74}$ The WTO Agreement, Art. XI.

${ }^{75}$ Id., Art. XII.

${ }^{76}$ For the reasons for accession and status of Ethiopia's WTO accession, see also <http://www.mfa.gov.et/internationalMore.php?pg=35> accessed 6 January 2018.

${ }^{77}$ For the status of Ethiopia's accession, see <http://www.wto.org/english/thewto_e/acc_e/status_e.htm> accessed 6 January 2018.

${ }^{78}$ Melaku Geboye (2008), 'Ethiopia's Reluctant Move to Join WTO: A Preliminary Look at Legal and Institutional Aspects of Accession', Journal of Ethiopian Law, Vol. 22 No. 1, p. 10. 
Regime (MFTR), a crucial document that is prepared in accordance with the detailed outline format provided by the WTO Secretariat. ${ }^{79}$ Once the MFTR is submitted, members of the Working Party start the questions and answers process in which they try to learn about the applicant country's trade and legal regime and identify areas of possible inconsistency with WTO Agreements. ${ }^{80}$ This multilateral process then moves on to negotiate "the terms of accession", which covers WTO rules on goods and TRIPS as well. ${ }^{81}$

The Working Party enquires into a country's trade and legal regimes with a view to identifying areas of inconsistency with WTO Agreements, and the TRIPS is one of such Agreements that have particular importance. With limited exceptions pertaining to the status of the applying country, a country that has applied for membership has to 'bring its house in order' and ensure that its IP related trade and legal regime is compatible with TRIPS.

As stated above, patent is one of the areas of protection under the TRIPS Agreement. Thus, notwithstanding the special and differential treatment and certain flexibilities that Ethiopia as an LDC is entitled to, its patent regime has to be consistent with TRIPS. There is an argument which is associated with the time when the Patent Law was enacted, which coincides with the entry into force of the Marrakesh Agreement establishing the WTO. Fikremarkos opines that the Patent Proclamation might have been informed by the TRIPS Agreement with the possible understanding on the part of the drafters that sooner or later the country would start the accession process and ensuring TRIPS compatibility of the Patent Proclamation was a forward looking approach. $^{82}$

The experience of certain countries which had acceded to the WTO indeed substantiates the argument that making national patent laws compatible with TRIPS is a prerequisite. Assessing China's accession, Maskus notes that external pressure has been an important impetus for legal change in the country, which culminated with the introduction of numerous changes in China's IPRs regime in anticipation of joining the WTO. ${ }^{83}$ There are also other examples in the same vein. Cambodia, for example, submitted its Memorandum on the Foreign Trade Regime (MFTR) in 1999, enacted a new Patent Law in January

\footnotetext{
${ }^{79}$ WT/ACC/1, in Melaku, supra note 78, p. 10.

${ }^{80}$ WT/ACC/10/Rev.3, 28 November 2005 in Melaku, supra note 78, p 10.

${ }^{81}$ Melaku, supra note 78, pp. 10-11.

${ }^{82}$ Fikremarkos Merso (2008), 'Ethiopia's Accession to the WTO: Does it Imply anything on Access to Affordable Medicines in Ethiopia?' Ethiopian Business Law Series, Vol. 2, pp. 166-167.

${ }^{83}$ Kieth Maskus (2002) 'Intellectual Property Rights in the WTO Accession Package: Assessing China's Reforms' available online at <siteresources.worldbank.org>maskus_tips> accessed 11 January 2018.
} 
2003 and was admitted to WTO in September of the same year. Saudi Arabia promulgated, inter alia, a new Patent Law in 2004 during the course of the accession process and became a member by the end of 2005. As noted earlier, the trend is also the same when one looks into the experience of original members of the WTO, particularly developing and least-developed ones, whereby they had to enact a new patent law or amend existing ones to ensure conformity with the TRIPS Agreement.

As noted, LDC members of the WTO are entitled to certain transitional arrangements in respect of the TRIPS Agreement. It may be argued that, even if the Patent Law is TRIPS compliant, Ethiopia may not (upon completion of the accession process) be obliged, as an LDC, to fully implement the TRIPS Agreement during the transitional period embodied under WTO rules. However, this may not work equally for original members of the WTO and those which became members through accession. ${ }^{84}$ This is because the obligations of acceding members are determined by their terms of accession and these countries may not necessarily be entitled to the rights accorded to existing LDC members. ${ }^{85}$ What the accession experience of Cambodia and Nepal suggests is that acceding countries may not necessarily be entitled to the rights of the LDCs, and WTO members and their fate is determined more by the terms of accession than the WTO rules. ${ }^{86}$

One may, therefore, argue that the Ethiopian Patent Law had its focus on WTO membership. And in order to do that, it was clear that one of the requirements was to make the Patent Law TRIPS compatible, because the TRIPS is one of the Agreements in the WTO single undertakings package. It can further be argued that there was no way for the drafters of the Ethiopian Patent Law to foresee the transitional arrangements and the flexibilities that were made available for countries like Ethiopia, even if special and differential treatment of LDCs is not something new introduced by the TRIPS Agreement and subsequent WTO Decisions. That said, there seems to be no argument that going for a strong a patent law was not the right thing to do. After 25 years since

${ }^{84}$ The Marrakesh Agreement establishing the WTO envisages two kinds of membership: original membership and membership through accession. Once admitted to the WTO, all members have the same rights, irrespective of the mode of acquiring membership. Although such double standard between countries of the same level of development (witnessed throughout the years) defeats the provisions of Art. XX of the WTO Agreement, it has remained the trend.

${ }^{85}$ Fikremarkos, 'Ethiopia's Accession to the WTO' supra note 82, p. 190.

${ }^{86}$ R. Grynberg \& R. M. Joy (2004), 'The Accession of Vanuatu to the WTO -Lessons for the Multilateral Trading System', Journal of World Trade, 34, 159-73 in Fikremarkos, 'Ethiopia's Accession to the WTO', supra note 82, p. 190. 
Ethiopia's request to join the WTO, its concessions in the IP regime have been futile, and the accession process appears to have stalled.

\section{Bilateral Trade Agreements and the Globalization of Patents: The Cotonou Agreement and Ethiopian Patent Law}

\subsection{Bilateral Trade Agreements and Patents}

The world today is witnessing the proliferation of BTAs, whose underlying motivations are diverse. There are two broad categories of BTAs: the first are regional or country-specific BTAs and the second fall under subject-specific bilateral trade and cooperation agreements. ${ }^{87}$ There are a few agreements in the first category such as trade and investment framework agreements. They are initial agreements concerned with laying down the foundations for negotiations of a bilateral free-trade or investment agreement between two countries. ${ }^{88}$ There are also FTAs which deal with extensive issues like investment, where bilateral investment treaties establish the terms and conditions for private investment by nationals and companies of one state in another state. ${ }^{89}$ Bilateral cooperation, partnership and association agreements deal with market reforms, investment and IP protection. ${ }^{90}$ Under the second category, i.e. subject-specific bilateral treaties and agreements, we find bilateral science and research and development cooperation agreements and bilateral IP agreements. ${ }^{91}$

BTAs of various kinds have grown in number and membership. One of the interesting characteristics of most BTAs is that they do not make room for reservations to be made in respect of the provisions incorporated in the agreements. Accordingly, as with other issues, a country willing to be part of such agreements accepts every provision in a given agreement, including certain purely non-trade matters such as political aspects, poverty reduction, fight against terrorism, combating corruption, the provisions on human rights including IP protection. As will be seen later, the provisions on IP protection in most cases make reference to multilateral IP agreements and clearly provide that patent is among the IP rights to be protected.

One may notice the proliferation of BTAs since the turn of the century. This is particularly true since the adoption of the Doha Declaration. ${ }^{92}$ The adoption of

${ }^{87}$ Mohammed K El Said (2010), Public Health Related TRIPS-Plus Provisions in Bilateral Trade Agreements: A Policy Guide for Negotiators and Implementers in the WHO Eastern Mediterranean Region, WHO and ICTSD p. 47.

${ }^{88}$ Id., pp. 47-48.

${ }^{89}$ Id., pp. $48-49$.

${ }^{90}$ Id., pp. 51-52.

${ }^{91}$ Id., pp. 52-54.

${ }^{92}$ The Doha Declaration is the result of the WTO Fourth Ministerial Conference launched in Doha in 2001. In the area of IP, the Doha Declaration was successful in a number of 
this Declaration and, subsequently, of a decision aimed at facilitating the importation of medicines by developing countries without manufacturing capacity in pharmaceuticals, was an attempt to ensure, through the effective use of the permitted flexibilities; and this shows some balance in the implementation of the TRIPS Agreement and, in particular, it indicates that public health should be given priority in case of conflict with IP rules. ${ }^{93}$

Most developed countries, which were frustrated at the manner in which the TRIPS flexibilities were interpreted at Doha, turned to BTAs to get back what they believed to have lost at Doha by imposing stricter IP rules in these agreements. ${ }^{94}$ The wave of BTAs, particularly those by the US and EU with developing countries, ${ }^{95}$ represents a drastic setback in this respect, since they not only erode flexibilities but impose a number of additional obligations on states that can further restrict their endeavor in promoting access to medicine. ${ }^{96}$

These BTAs include a chapter on IP, and they further impose restrictions in the criteria of patentability, patent territory, patent duration and disclosure of clinical data, which restrict the flexibility otherwise provided by the TRIPS Agreement. ${ }^{97}$ The ones promoted by the US oblige partner signatory countries to extend the patent term to compensate for 'unreasonable' delays 'beyond' a certain period (a) in the procedures for the marketing approval of a medicine and (b) in the examination of patent applications. ${ }^{98}$ A very good example is the US-CAFTA Agreement (US-Central America Free Trade Agreement, which provides that "each party shall make available a restoration of the patent term to

important aspects: granting of compulsory licenses, an umbrella clarification and flexibility, moratorium for LDCs not to observe pharmaceutical for another 10 years i.e. until 2016, and allowing eligible importing country under the system to request an exporting country to manufacture the patented product all or predominantly for export to the requesting eligible importing country. See Centre for Human Rights Access to Medicines Course Book (Reader, Unpublished), Advanced Human Rights Course on Intellectual Property, Human Rights and Access to Medicines, pp. 98-99.

${ }^{93}$ Carlos Correa (2006), 'Implications of Bilateral Free Trade Agreements on Access to Medicines' Bulletin of the World Health Organization; 84, p. 400.

${ }^{94}$ Access to Medicines Course Book (Reader), supra note 92, p. 208.

${ }^{95}$ The US has initiated 11 bilateral and regional free trade agreements with 23 countries. For example, in justifying the reasons for entering into negotiations with Southern African Countries Union (SACU), the US Trade Representative's letter to the Congress read "we plan to use our negotiations with the SACU countries to address barriers in these countries to US exports...including inadequate protection of IP rights".

${ }^{96}$ Correa, supra note 93, p. 400.

${ }^{97}$ N Lalitha (2008), 'Doha Declaration and Public Health Issues', Journal of Intellectual Property Rights, Vol. 13, pp. 411-412.

${ }^{98}$ Correa, supra note 93, p. 400. 
compensate the patent owner for unreasonable curtailment of the effective patent term as a result of marketing approval process". ${ }^{99}$

\subsection{The Cotonou Agreement and its influence on Ethiopian patent law}

With the decolonization process gaining ground in the early 1960s, the hegemony came back through the backdoor, this time with a trade cooperation tag. This culminated in the signing of the Yaoundé Convention in 1963. In 1975, forty-six African, Caribbean and Pacific (ACP) States, largely made up of former colonies of European states, entered into an agreement to formally establish the ACP Group of States in order to consolidate and strengthen existing solidarity among them and promote understanding between ACP peoples and governments. ${ }^{100}$ In 2000 , representatives from the EU and seventyseven ACP countries met in Cotonou, Benin to sign a trade and aid accord to replace the Lomé IV Convention, which had expired earlier that year, and to set the seal on a quarter of a century of cooperation between a number of partners from North and South. ${ }^{101}$

In the 2000s, the European Commission explicitly included a TRIPS-plus mandate in its trade goals, stating that "the EU should seek to strengthen IPR provisions in future bilateral agreements and the enforcement of existing commitments". ${ }^{102}$ Initial public statements by the EU suggested that IP would not play a significant part in EPAs (European Partnership Agreements) and consistently noted that the EU does not need market access to the ACP Countries and that the goal of the Agreement is the development of the ACP Countries. ${ }^{103}$ However, recent proposals, papers and statements from the EU, including the new EU Trade Policy review paper suggest that the Agreements are a crucial element of the EU's global trade strategy and that, in particular, the EU is seeking higher IP standards, which includes patents. ${ }^{104}$

Indeed, while the Cotonou Agreement notes the need to take into account different levels of development, it has several TRIPS-plus aspects, including recognition of the need to accede to all relevant international conventions on IP for patent protection of biotechnological inventions, and for the legal protection

\footnotetext{
${ }^{99}$ Lalitha, supra note 97, p. 412.

${ }^{100}$ Nsongurua Udombana (2004), 'Back to Basics: The ACP-EU Cotonou Trade Agreement and Challenges for the African Union', Texas International Law Journal, Vol. 40, p. 63.

${ }^{101}$ Id., p. 60.

102 European Commission "Global Europe: competing in the world", EC Policy Review, October 4, 2006, available at <http://ec.europa.eu/trade/issues/sectoral/competitiveness/global_europe_en.htm>

${ }^{103}$ Center for International Environmental Law, 'The European Approach to Intellectual Property in European Partnership Agreements with the African, Caribbean and Pacific Group of Countries' Discussion Paper, April 2007, p. 1.

${ }^{104}$ Ibid.
} 
of non-original databases (also not required by TRIPS). ${ }^{105}$ This goes beyond TRIPS which does not call on countries to accede to any additional international IP conventions. It is, therefore, clear that the EU has a long history of including IP in its bilateral agreements, and that the majority of the negotiated EU BTAs reflect undertakings to adopt higher standards of IP protection, i.e. "to provide," or "to ensure," "suitable and effective" or "adequate and effective levels of protection of IP rights in accordance with the highest international standards". ${ }^{106}$

There are also a number of EU official documents which suggest that agreements, which have become part of the EU trade strategy such as the Cotonou Agreement are important tools to enforce EU IP/patent interests. The "Global Europe -Competing in the World" Report emphasizes on the importance of market access and IP as tools for greater European advancement. ${ }^{107}$ Part iii of Section 3.2 of the Report deals with "Opening Markets Abroad" and states that the EU "will require a sharper focus on market opening and stronger rules in new trade areas of economic importance, notably IP. ${ }^{108}$ According to Part ii of Section 4.2 relating to 'Free Trade Agreements', "FTAs should include stronger provisions for IPR and competition, including, for example, provisions on enforcement of IP rights along the lines of the EC Enforcement Directive". ${ }^{109}$ Part v of the same Section also states that "the EU should seek to strengthen IP provisions in future bilateral agreements and the enforcement of existing commitments in order to reduce IPR violations..."

The Cotonou Agreement provides that the Parties to the Agreement recognize the need to ensure an adequate and effective level of protection of intellectual, industrial and commercial property rights, and other rights covered by TRIPS in line with the international standards with a view to reducing distortions and impediments to bilateral trade. ${ }^{111}$ This provision clearly represents a BTA attempting to enforce the TRIPS Agreement on countries such as Ethiopia that are not WTO members, even if the provision is framed in such a way that it acknowledges the importance of TRIPS compliant IP regime in the ACP Countries for reducing distortions and impediments to bilateral trade.

Also interesting is that Parties to the Cotonou Agreement underline the importance of adherence to the TRIPS Agreement and have agreed on the need to accede to all relevant international conventions on intellectual, industrial and

\footnotetext{
${ }^{105}$ Deere, supra note 3, p. 153.

${ }^{106}$ Center for International Environmental Law, supra note 103, p. 4.

${ }^{107}$ Ibid.

108 Ibid.

${ }^{109}$ Ibid.

${ }^{110}$ Id., pp. 4 -5.

111 The Cotonou Agreement, Art. 46 (1).
} 
commercial property under Part I of the TRIPS Agreement, in line with their level of development. ${ }^{12}$ Although the provisions employ soft words such as '...underline the importance...' and '....agree on the need to accede to...', they still target at accession to TRIPS and the adherence of ACP countries to international agreements, even if such adherence were to compromise their domestic policy objectives.

Ethiopia was one of the Parties to the ACP-EU Partnership Agreement signed in Cotonou in 2001 and ratified the Agreement through Proclamation No. 242/2001. According to the Proclamation, the Ministry of Economic Development and Cooperation was empowered to implement the Cotonou Agreement. ${ }^{13}$ There was no mention of other government organs under Proclamation No. 242/2001, with which the Ministry of Economic Development and Cooperation was to collaborate in implementing the Agreement. However, under Proclamation No. 524/2007 which ratified the amending Agreement, the Ministry of Finance and Economic Development (MoFED) was authorized to implement the Cotonou Agreement in collaboration with appropriate government organs. ${ }^{114}$ This provision is repeated verbatim in the Proclamation which ratified the further amendment to the Cotonou Agreement. ${ }^{115}$

As the Cotonou Agreement incorporates provisions on IP, one of the Government organs that MoFED is expected to collaborate with in implementing the Cotonou Agreement is the Ethiopian Intellectual Property Office (EIPO), which is established pursuant to Proclamation No. 320/2003. One of the objectives of the Office is to facilitate the provision of adequate legal protection for and exploitation of IP in the country, which includes patent. ${ }^{116}$ This is also clear from the reading of Article 16 of the Proclamation whereby the Office assumed rights and obligations of the Ethiopian Science and Technology Commission concerning patents and related matters under Proclamation No. $7 / 1995$ as well as the Patent Proclamation. Furthermore, one of the duties of the Office is to implement and/or follow up the implementation of international IP agreements to which Ethiopia is a party. ${ }^{117}$ MoFED is, therefore, expected to collaborate with EIPO in implementing IP related provisions of the Cotonou Agreement.

\footnotetext{
${ }^{112}$ Id., Art. 46 (2) and (3).

${ }^{113}$ The Cotonou Agreement Ratification Proc. No. 242/2001, $7^{\text {th }}$ Year No. 30, Art. 3.

114 The Cotonou ACP-EU Partnership Agreement Amendment Ratification Proclamation No. 524/2007, $13^{\text {th }}$ Year No. 27, Art. 3.

115 The Cotonou ACP-EU Partnership Agreement Amendment Ratification Proclamation No. 779/2012, $19^{\text {th }}$ Year No. 21, Art. 3.

116 Ethiopian Intellectual Property Office Establishment Proclamation No. 320/2003, $9^{\text {th }}$ Year No. 40, Arts. 2 (1) and (2) and Art. 5.

${ }^{117}$ Id., Art. 6 (12).
} 
One may ask what the Cotonou Agreement brings to the Ethiopian Patent system, as it already is largely TRIPS compliant. For one thing, Ethiopia is not yet a member of the Paris Convention. As a Party to the Cotonou Agreement, Ethiopia has undertaken to accede to all international conventions on IP, including the Paris Convention. Moreover, the Parties have agreed to strengthen their cooperation with regard to IP, which, inter alia, extends to the preparation of laws and regulations for the protection and enforcement of IP rights, the prevention of the abuse of such rights by right holders and the infringement of such rights by competitors, the establishment and reinforcement of domestic and regional offices and other agencies including support for regional IP organizations involved in enforcement and protection, including the training of personnel. ${ }^{118}$ In view of current realities, the term 'cooperation' apparently means European influence in the ACP Countries in the abovementioned areas and certainly, it is not a two way relationship between the EU and the ACP Countries.

\section{The Generalized System of Preferences and the Globalization of Patents: AGOA and the Ethiopian Patent Law}

\subsection{The Generalized System of Preferences}

Preferential treatment of trade was considered as one of the most trade distorting manifestations of the pre-GATT period. In response to this challenge, the MostFavored Nations Treatment Principle (MFN) appears in the very first Article of GATT 1948. According to the principle, GATT members treat every contracting party as the most favored, and as a consequence, a favor granted to a party will also be made available for all the trading partners. It is not surprising that the principle forms the cornerstone of the other Agreements in the WTO package.

The MFN Principle has a few exceptions, and the GSP is one of these exceptions which grants unilateral arrangements to developing countries and LDCs to export their products for a reduced [or no] tariff. A few practical issues were not clear for some time. However, the end of the Tokyo Round in 1979 brought up clarification on such arrangements, when developing countries secured adoption of the Enabling Clause, a permanent deviation from MFN by joint decision of the GATT Contracting Parties. ${ }^{119}$ The Clause states that notwithstanding GATT Article I, "Contracting Parties may accord differential and more favorable treatment to developing countries, without according such

\footnotetext{
${ }^{118}$ The Cotonou Agreement, Art. 46 (6).

${ }^{119}$ See Jeanne Grimmett (2011), 'Trade Preferences for Developing Countries and the World Trade Organization (WTO)' Congressional Research Service 1-2 available at <https://pdfs.semanticscholar.org/9b25/e78969d3fbea63f27f933ec5d349ef8b44f7.pdf>
} 
treatment to other Contracting Parties" and this exception applies to (1) preferential tariff Trade Preferences for Developing Countries; (2) multilateral nontariff preferences negotiated under GATT auspices; (3) multilateral arrangements among less developed countries; and (4) special treatment of LDCs in the context of any general or specific measures in favor of developing countries. ${ }^{120}$

The US has been administering GSPs with many countries. According to the Office of the United States Trade Representative, US trade preferences such as the GSP is the largest and oldest US trade preference program that provides opportunities for many of the world's poorest countries to use trade in pursuits of economic growth and to climb out of poverty. ${ }^{121}$ The US currently administers and has obtained waivers for the Caribbean Basin Economic Recovery Act (CBERA), the Andean Trade Preference Act (ATP), and the African Growth and Opportunity Act (AGOA) which extend duty-free treatment and waiver of other conditions such as non-discrimination in administering quotas. ${ }^{122}$

\subsection{AGOA and US influence on Sub-Saharan African countries}

Irrespective of the reasons provided in an attempt to justify conditionalities attached to aid or loan, it has been a while since they have become a global phenomenon. The IMF has been one of the international institutions which have pursued this trend. In exchange for financial support, borrowing countries agree to implement a package of obligatory policy reforms (conditionality), phased over one or more years, and its implementation is assessed on a regular basis. ${ }^{123}$

Apart from the international financial institutions, trade benefit initiatives such as AGOA have also been attracting attention as conditionalities continue to be attached, some of which have nothing to do with trade. AGOA is one of the examples in this category. It was signed into law by President Clinton in 2000 with the objective of expanding US trade and investment with sub-Saharan Africa, to stimulate economic growth, to encourage economic integration, and to facilitate sub-Saharan Africa's integration into the global economy. ${ }^{124}$ The US Congress requires the President to determine annually the sub-Saharan African countries that are eligible for AGOA benefits based on certain criteria, including progress towards the establishment of a market-based economy, rule of law,

\footnotetext{
${ }^{120}$ Ibid.

${ }^{121} \mathrm{See}<\mathrm{https}$ //ustr.gov/issue-areas/trade-development/preference-programs/generalizedsystem-preference-gsp > accessed 9 January 2018.

${ }^{122}$ Grimmett, supra note 119 , pp. 3-4.

${ }^{123}$ Alexander Kentikelenis et al. (2016), 'IMF Conditionality and Development Policy Space, 1985-2014', Review of International Political Economy 6, available at <http://dx.doi.org/10.1080/09692290.2016.1174953> accessed 12 January 2018.

${ }^{124} \mathrm{See}<\mathrm{https}$ ///ustr.gov/issue-areas/trade-development/preference-programs/african-growthand-opportunity-act-agoa> accessed 9 January 2018.
} 
economic policies to reduce poverty, protection of internationally recognized worker rights, and efforts to combat corruption. ${ }^{125}$ Hence, if the President for whatever reason holds that a country is "engaged in activities that undermine US national security or foreign policy interests" or "engaged in gross violations of internationally recognized human rights or provided support for acts of international terrorism and cooperated in international efforts to eliminate human rights violations and terrorist activities", ${ }^{26}$ the country will not be eligible for the opportunity.

GSP dictates are purely unilateral in nature in the sense that the country which grants it to another may withdraw it anytime. Yet, AGOA goes a step further as the eligibility of sub-Saharan countries is put under the mercy of an incumbent US President. One may also presume the influence of the big US corporations behind selecting the African countries eligible for the opportunity. Mushita, for example, asks if it is African countries or American companies that really benefit from the arrangement. ${ }^{127}$

The determinative eligibility criteria of AGOA demand that a country "has established, or is making continual progress toward establishing," inter alia:

a) a market-based economy that protects private property rights;

b) the rule of law, political pluralism, and the right to due process, a fair trial, and equal protection under the law;

c) the elimination of barriers to United States trade and investment;

d) economic policies to reduce poverty, increase the availability of health care and educational opportunities;

e) a system to combat corruption and bribery [and];

f) protection of internationally recognized worker rights, including the right of association, [and] the right to organize and bargain collectively. ${ }^{128}$

125 Ibid.

${ }^{126}$ David Fuhr and Zachary Klughaupt (2004), 'The IMF and AGOA: A Comparative Analysis of Conditionality', Duke Journal of Comparative and International Law, Vol. 14.

${ }^{127}$ Mushita criticizes AGOA because (a) the eligibility criteria and conditionality on the beneficiary countries are based on free market models designed to create markets for US corporations in the name of trade liberalization and privatization and (b) the countries, as a strategic market for US producers and investors, are being forced to implement WTO/TRIPS provisions through the backdoor for the benefit of American transnational corporations on a bilateral basis. T Mushita (2007), 'An African Response to AGOA' in Southern African Economist, Vol. 14, No 6, p. 17.

128 AGOA, Art. 104 in Fuhr and Klughaupt, supra note 164, p. 137. It should be noted, however, that IP or the eligibility requirement found under Art. 104 are not the only factors that the U.S. President takes into consideration in determining eligibility of a 
It is easy to see that most of these eligibility requirements have nothing to do with trade issues, particularly when weighed against the objectives of AGOA itself. Moreover, inserting a clause on the "elimination of barriers to US trade and investment" is bizarre and reinforces the argument that AGOA in fact appears in the interest of the US, and not solely in the interests of African countries. It also conveniently refutes the claim that AGOA is non-reciprocal. Although eligible countries do and will continue to benefit from AGOA, the claim that the US is benefiting from the initiative in pursuing its trade and political objectives (in the countries it selects as eligible) is palatable.

\subsection{AGOA and its impact on Ethiopia}

In the Trade and Tariff Act of 1984, Congress clearly linked trade and IP, where IP was a 'new' trade issue, along with services. ${ }^{129}$ The Trade Act made IP infringement a subject of the National Trade Estimates Report on Foreign Trade Barriers, a cause of action under Section 301, and a consideration in the designation of countries for inclusion in the GSP. ${ }^{130}$ The US held bilateral discussions with many countries to improve their IP regimes and enforcement by, inter alia, using the GSP review process. ${ }^{131}$

The provision of immediate importance is found under Article 104(c) of AGOA where it is required to afford protection to IP rights to US investors. As effective IP protection and enforcement mechanism is one of the criteria for determining eligibility of sub-Saharan African Countries in AGOA, it remains one of the tools for the US Government (as well as companies) to impose their interests. ${ }^{132}$ The International Intellectual Property Alliance, for example, noted that the US Government's AGOA review is one of the few regularly occurring opportunities to examine IP protection and enforcement in AGOA-eligible countries and to provide guidance to make those mechanisms more effective. ${ }^{133}$

country to benefit from AGOA. There are also other strange factors that determine eligibility, such as human rights record and democracy.

129 Richard Morford (1989), 'Intellectual Property Protection: A United States Priority', Georgia Journal of International and Comparative Law, Vol 19:2, p. 337.

${ }^{130}$ Ibid.

${ }^{131}$ Id., pp. 338-339.

${ }^{132}$ It is stating the obvious that the US takes issues relating to US IP rights seriously. For example, in 1997 in a dispute over IP protection, the US removed half of Argentina's GSP privileges. Also in 2001, Ukraine was suspended from the GSP for reasons of IP rights. See Generalized System of Preferences: Handbook on the Scheme of the United States of America UNCTAD/ITCD/TSB/Misc.58/Rev.2 available at:

<http://unctad.org/en/Pages/DITC/GSP/Generalized-System-of-Preferences.aspx > accessed 13 January 2018.

${ }^{133}$ Filing of the International Intellectual Property Alliance (IIPA) Public Comments on Annual Review of AGOA Country Eligibility October 2013, available at 
The above discussion shows how AGOA has become a very effective instrument to enforce US IP interests in African countries. For instance, South Africa is one of the sub-Saharan African countries that have relatively optimal benefits from the AGOA initiative. In 2013, there was an effort to revise the South African IP Policy, which was motivated by the need to promote access to medicines particularly for people living with HIV. Two years later, the American Chamber of Commerce in South Africa (which represents 250 companies operating in South Africa, including several multinational pharmaceutical firms) urged the US Trade Representative to use its review of AGOA to pressure South Africa's Government to revise the draft policy in favor of US Companies, which many civil societies vehemently opposed and rallied against. ${ }^{134}$ This clearly shows how US companies who have interests in Africa put pressure on the US Government to make effective use of AGOA to serve their interests, essentially by exerting pressures against the domestic policy space of the eligible countries.

Insofar as the objectives of arrangements is to establish commitments for countries to significantly strengthen their domestic enforcement procedures through different mechanisms, ${ }^{135}$ patent protection in Ethiopia cannot be free from the interests of foreign-based companies. As indicated earlier, failing to protect patent may be a cause for disqualification from AGOA, an initiative which, if Ethiopia were to benefit from it, considerably increases the value of exports eligible for preferential market access to the US. ${ }^{136}$ The experience of other countries under the AGOA initiative also reinforces this argument.

\section{Concluding Remarks}

This article has attempted to examine the impact of globalization on patent laws of developing countries. As the experience of developing countries indicates, developed countries continue to use various international agreements to enforce their interests. The TRIPS Agreement is a prime suspect in this regard, as it requires developing countries to enact new patent laws or amend existing ones and give patent protection for products and processes in any field of technology. Following certain flexibilities and transitional arrangements (granted to certain developing and LDCs as the result of the Doha Declaration), developed countries started to negotiate and enter into different sorts of BTAs with a view

\footnotetext{
<http://www.iipawebsite.com/pdf/2013_Oct25_AGOA_Annual_Report.PDF> accessed 13 January 2018.

134 <agoa.info/news/article/5788-sa-trade-official-digs-in-on-intellectual-propertydraft.html> accessed 13 January 2018.

${ }^{135}$ Adusei, supra note 10, p. 91.

136 See Deere, supra note 3, p. 269.
} 
to reclaiming what they thought they would lose as a result of the Doha Declaration or any other development in the field. Moreover, BTAs and the benefits that they entail appear non-reciprocal. The important place accorded to IP/patent protection in both the Cotonou Agreement and AGOA makes it clear that the initiatives are in fact important tools to ensure that IP interests of foreign-based companies are enforced.

As discussed earlier, Ethiopia has a strong and a TRIPS compliant Patent Law. In light of the experience of some developing countries, Ethiopia may further be forced to give up its entitlements at the business end of the accession process. Cambodia, for example, had been a subject of TRIPS-plus measures, as it was forced to ratify the International Union for the Protection of New Varieties of Plants Convention and adhere to the entire TRIPS Agreement by January 2007 (as opposed to 2021) including pharmaceutical patents (as opposed to 2033).

All these experiences lead to one direction. With the growth in the Ethiopian domestic production capacity of some inventions, it is to be expected that the trade agreements may be used to put pressure on Ethiopia to maintain the existing patent regime. The pharmaceutical industry offers a good example in this regard. There is said to be a glimmer of hope in Ethiopia when it comes to medicines, as the pharmaceutical sector is expected to make progress in the coming years. For example, there is the 10 years Strategy and Plan of Action for Pharmaceutical Manufacturing Development. ${ }^{137}$ To this end, the pharmaceutical industry zone (that the Government is planning to make available for pharmaceutical producers) is being built in the outskirts of Addis Ababa. If these and other initiatives succeed, the pharmaceutical industry can produce important generic medicines, and this will certainly induce pressures to force Ethiopia to come up with stricter patent protection and enforcement measures by using the arrangements discussed above.

Ethiopia has already surrendered too much by opting for a strong Patent Law and should not surrender anymore as it would result in unprecedented shrinking of its domestic policy space for the sake of getting (if at all) some trade benefits out of WTO membership. The same holds true in negotiating and concluding BTAs of any kind, as, needless to say, public interest prevails over any trade interest.

${ }^{137}$ Federal Democratic Republic of Ethiopia, Ministry of Health and Ministry of Industry, National Strategy and Plan of Action for Pharmaceutical Manufacturing Development in Ethiopia: Developing the Pharmaceutical Industry and Improving Access (2015-2025) available at <http://apps.who.int/medicinedocs/documents/s21999en.pdf> accessed 18 January 2018. 